\title{
New species of Diplectanum (Monogenoidea: Diplectanidae), and proposal of a new genus of the Dactylogyridae from the gills of gerreid fishes (Teleostei) from Mexico and Panama
}

\author{
Edgar F. Mendoza Franco ${ }^{1,2}$, Dominique G. Roche ${ }^{1,3}$ and Mark E. Torchin ${ }^{1}$ \\ ${ }^{1}$ Smithsonian Tropical Research Institute, Apartado Postal 0843-03092 Balboa, Ancon, Panamá, Republic of Panama; \\ ${ }^{2}$ Institute of Parasitology, Biology Centre of the Academy of Sciences of the Czech Republic, Branišovská 31, 37005 České \\ Budějovice, Czech Republic; \\ ${ }^{3}$ Department of Biology, McGill University, 1205 Avenue Doctor Penfield, Montreal, Quebec, H3A 1B1, Canada
}

Key words: Monogenoidea, Diplectanidae, Dactylogyridae, Diplectanum, Octouncuhaptor, Diplectanum gatunense, Diplectanum mexicanum, Octouncuhaptor eugerrei, Eugerres brasilianus, Diapterus rhombeus, Panama, Mexico

\begin{abstract}
While investigating the parasites of several marine fishes from the Western Atlantic, the Southern Gulf of Mexico and Central America (Panama), the following monogenoidean species from the gills of gerreid fishes (Gerreidae) were found: Diplectanum gatunense sp. n. (Diplectanidae) and Octouncuhaptor eugerrei gen. et sp. n. (Dactylogyridae) in Eugerres brasilianus (Cuvier) from Gatun Lake in the Panama Canal Watershed, and Diplectanum mexicanum sp. n. in Diapterus rhombeus (Cuvier) from the coast of Campeche State, Mexico. New diplectanid species are distinguished from other species of the genus by the general morphology of the copulatory complex and by the shape of the anchors and bars on the haptor. Octouncuhaptor gen. n. is proposed for its new species having slightly overlapping gonads (testis posterodorsal to the ovary), a dextrolateral vaginal aperture, a copulatory complex consisting of a coiled male copulatory organ with counterclockwise rings with the base articulated to the accessory piece, 8 pairs of hooks and the absence of anchors and bars on haptor. Our analysis of morphological features of Diplectanum species on gerreids evidences that these parasites more closely resemble each other than the known species from sciaenids suggesting that split between gerreids and sciaenids resulted in parasite speciation.
\end{abstract}

There are 11 species of genus Diplectanum Diesing, 1858 (Diplectanidae) reported from the gills of marine and freshwater sciaenid (Perciformes) hosts from the Western Atlantic (Santos et al. 2002). Six of these were described from Plagioscion spp. in freshwaters of South America (Brazil) from which some are also reported from French Guiana and Peru (see Kohn and Cohen 1998): Diplectanum cayennense Euzet et Durette-Desset, 1974, Diplectanum decorum Kritsky et Thatcher, 1984, Diplectanum gymnopeus Kritsky et Thatcher, 1984, Diplectanum hilum Kritsky et Thatcher, 1984, Diplectanum pescadae Kritsky et Thatcher, 1984 and Diplectanum piscinarius Kritsky et Thatcher, 1984. Similarly, Diplectanum copiosum Boeger, Fehlauer et Marques, 2006 was described from Pachyurus junki Soares et Casatti (type host) and Petilipinnis grunniens Jardine et Schomburgk (Pachyurinae) in Brazil (Kritsky and Thatcher 1984, Boeger et al. 2006). In marine and brackish water, sciaenid and gerreid fishes have been reported as hosts of Diplectanum spp.: Diplectanum squamatum Santos, Timi et Gibson, 2002 from Cynoscion guatucupa Cuvier off the coast of Mar del Plata in Argentina; Diplectanum monticellii Domingues et Boeger, 2003 from Cynoscion leiarchus (Cuvier) (Sciaenidae) in the Guaratuba Bay, Paraná, Brazil; Di- plectanum magnodiscatum Fuentes-Zambrano, 1997 from Eugerres plumieri (Cuvier) (Gerreidae) in the Laguna de la Restinga in Venezuela; and Diplectanum wenningeri (Mizelle et Blatz, 1941) Oliver, 1987 (reported as Neodiplectanum wenningeri) from Eucinostomus gula (Quoy et Gaimard) (Gerreidae) and Eucinostomus plumieri (Cuvier) from the Everglades of Florida, USA, and the Caribbean Sea (Chetumal Bay, Mexico), respectively (see Mizelle and Blatz 1941, Fuentes-Zambrano 1997, Santos et al. 2002, Domingues and Boeger 2003, Aguirre-Macedo et al. 2007).

During a survey of gill monogenoidean parasites of marine gerreid fishes, Eugerres brasilianus (Cuvier) and Diapterus rhombeus (Cuvier) from Gatun Lake, Panama, and the coast of Campeche State, Mexico (Gulf of Mexico), two new species of Diplectanum and one new genus and species of the Dactylogyridae were found. Herein, descriptions of these new species and information about their prevalence and the intensity of infections at each sampling site are provided.

\section{MATERIALS AND METHODS}

Specimens of Eugerres brasilianus were caught using a gill net during June 2007, near Barro Colorado Island in Gatun Lake, Panama $\left(9^{\circ} 10^{\prime} 2.68^{\prime \prime} \mathrm{N} ; 7^{\circ} 50^{\prime} 13.90^{\prime \prime} \mathrm{W}\right)$. Fish were 
kept on ice for less than 12 hours before their gills were fixed in $10 \%$ formaldehyde solution for examination. Specimens of Diapterus rhombeus were collected in July 2005 along the coast of Campeche State, Mexico (18 $48^{\prime} 45^{\prime \prime} \mathrm{N}$; 92 $2^{\circ} 03^{\prime}$ $45^{\prime}$ 'W). Entire specimens of $D$. rhombeus were fixed in formalin $(10 \%)$ immediately after capture, and the gills were subsequently removed and stored for later examination. Parasites recovered from both host species were stained with Gomori's trichrome and mounted in Canada balsam. In addition, some specimens were mounted unstained in Gray and Wess's medium to obtain measurements and line drawings of the copulatory complex and haptoral structures. All other measurements were obtained from unflattened specimens stained with Gomori's trichrome. Drawings were made with a drawing tube using a compound microscope with a Nomarski differential interference contrast. Measurements, in micrometres, represent straight-line distances between extreme points and are presented as the mean \pm standard deviation when appropriate, followed by the range, and the number (n) of structures measured, in parentheses. Body length includes the haptor. Numbering of hook pairs for the new species of Diplectanum follows the scheme illustrated in Kritsky et al. (2000). Direction of the coil (when present) of the copulatory organ (i.e. counterclockwise) was determined using the procedure suggested by Kritsky et al. (1985). Type specimens are deposited in the National Helminthological Collection of Mexico (CNHE), Institute of Biology, National Autonomous University of Mexico, Mexico; the helminthological collection of the Institute of Parasitology, Biology Centre of the Academy of Sciences of the Czech Republic, České Budějovice (IPCAS); and the United States National Parasite Collection, Beltsville, Maryland (USNPC) as indicated in the respective descriptions. For comparative purposes, the following specimens were examined: five cotypes and two voucher specimens of Neodiplectanum wenningeri (USNPC 36823, 99639). The names of the hosts are consistent with FishBase (Froese and Pauly 2008).

\section{DESCRIPTIONS}

\section{Diplectanum gatunense sp. $\mathrm{n}$.}

Figs. 1-4, 6-9

Description (based on 37 specimens). Body $575 \pm 94$ (260-787; n = 32) long, broad posteriorly; $108 \pm 11$ $(87-130 ; n=32)$ wide at level of germarium. Tegument scaled on all surfaces of posterior trunk, peduncle; scales plate-like, lightly sclerotized, directed anteriorly. Four groups of head organs moderately developed in cephalic lobes; cephalic glands at level of pharynx. Eyes four; members of posterior pair larger and closer together than members of anterior pair; accessory granules usually absent or few in cephalic area. Pharynx subspherical, $35 \pm 3(31-42 ; \mathrm{n}=30)$ in diameter; oesophagus short. Peduncle moderately long; haptor $158 \pm$ $15(140-205 ; \mathrm{n}=27)$ wide. Squamodiscs subovate, ventral and dorsal; each formed by approximately 23 24 rings of phalangiform sclerites; anterior rings concentric, progressively tending to form straight line posteriorly, covering almost all portion of haptor; squamodisc 125 (122-127; $\mathrm{n}=4)$ long, 142 (135-160; $\mathrm{n}=4$ ) wide. Anchors similar, each with elongate deep root, horizontal superficial root, straight shaft, short point extending to level of tip of superficial root; ventral anchor $40(38-41 ; \mathrm{n}=8)$ long, base $20(19-21 ; \mathrm{n}=6)$ wide; dorsal anchor $34 \pm 2(30-36 ; \mathrm{n}=26)$ long, base $20(19-21 ; \mathrm{n}=6)$ wide. Ventral bar $125(114-136 ; \mathrm{n}=$ 14) long, narrow, elongate, with delicate tapered ends directed anteriorly, medially hollow; paired dorsal bar $53 \pm 3(50-58 ; n=25)$ long, medially expanded. Hooks similar, with proximally recurved shank, slightly depressed thumb and short recurved point; filamentous hooklet $(\mathrm{FH})$ loop nearly shank length; each $13(\mathrm{n}=11)$ long. Male copulatory organ (MCO) $73 \pm 3$ (64-78; $\mathrm{n}=$ 35) long, straight tube, elongate, composed of 2 nested tubes (i.e. terminal male genital appears as a tube within a tube), distally acute. Accessory piece enlarged, comprising pyriform tip with delicate indentations on margins, followed by proximal fringe. Testis $29(21-35 ; \mathrm{n}=$ 7) wide, subspherical; course of vas deferens in relation to gut not observed; seminal vesicle a simple dilation of vas deferens, lying along body midline; prostatic reservoir pyriform, divided into 2 bands, lying dorsal to MCO; prostatic cells (glands) anteroventral to MCO. Germarium $47(40-55 ; \mathrm{n}=8)$ wide, $55(40-75 ; \mathrm{n}=19)$ long, looping right intestinal caecum; oviduct and ootype not observed; vaginal duct sclerotized, slender, arising from a small seminal receptacle lying to left of body midline, distally twisted, funnel-shaped aperture; vitellaria dense throughout trunk, except in region of reproductive organs.

$\mathrm{T}$ y $\mathrm{p}$ e $\mathrm{h}$ o s t : Brazilian mojarra, Eugerres brasilianus (Cuvier) (Perciformes: Gerreidae).

Site of infection: Gills.

Type locality and collection date: Gatun Lake, Panama Canal Watershed (9¹0'2.68'’ N; 7950'13.90'’ W), June 2007.

S pe c i m en s depos it e d: Holotype, CNHE (6032); 14 paratypes, CNHE (6033), 9 paratypes, IPCAS (M-466) and 13 paratypes, USNPC (100847).

Prevalence and intensity of infection: Ten fish (mean total length $20 \mathrm{~cm}$; range 18-21) infected of $10 \mathrm{ex}-$ amined (100\%); intensity 3-34 worms, mean 22 worms.

E t y m o log y: The specific name of this species reflects the location (i.e., Gatun Lake) from which this species was found.

\section{Remarks}

Based on the presence of a dorsal and a ventral squamodiscs, three bars and two pairs of anchors on the haptor, and a sclerotized tubular copulatory organ (Oliver 1987, 1993), this species is considered a new member of Diplectanum. Diplectanum gatunense most closely resembles Diplectanum wenningeri originally described (as Neodiplectanum wenningeri) from Eucinostomus gula in Florida, USA, and D. magnodiscatum from Eugerres plumieri in Venezuela (Mizelle and Blatz 1941, Fuentes-Zambrano 1997). Diplectanum gatunense and these two latter diplectanid species share 


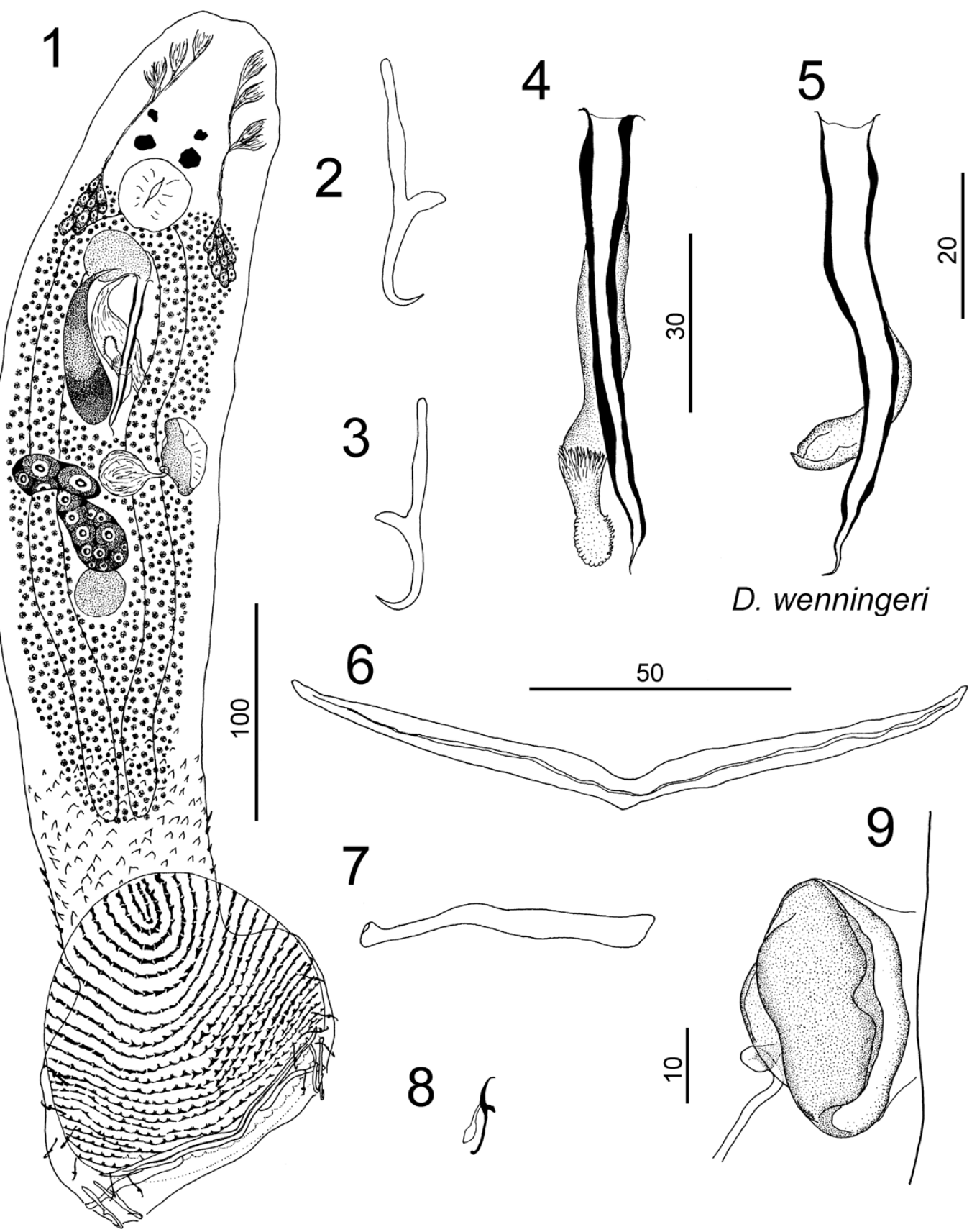

Figs. 1-4, 6-9. Diplectanum gatunense sp. n. Fig. 5. Copulatory complex of D. wenningeri (cotype USNPC 36823 ). Fig. 1. Whole mount (ventral, composite). Fig. 2. Ventral anchor. Fig. 3. Dorsal anchor. Fig. 4. Copulatory complex (ventral). Fig. 6. Ventral bar. Fig. 7. Dorsal bar. Fig. 8. Hook. Fig. 9. Vagina. Scale bars: Fig. $1=100 \mu \mathrm{m}$; Figs. 2-4, 7, $8=30 \mu \mathrm{m}$; Fig. $5=20$ $\mu \mathrm{m}$; Fig. $6=50 \mu \mathrm{m}$; Fig. $9=10 \mu \mathrm{m}$.

the following morphological features: 1) 4 eyespots, 2) relatively similar size of the copulatory complex (64-78 vs. 60-70 in five cotypes plus two voucher specimens [USNPC 36823, 99639] of D. wenningeri), 3) presence of the accessory piece, and 4) squamodiscs covering almost all portion of the haptor (see Mizelle and Blatz 1941, Fuentes-Zambrano 1997). Furthermore, D. gatunense, D. wenningeri and D. magnodiscatum occur on gerreid fishes and in the same geographical area (i.e., Western Atlantic). Diplectanum gatunense differs from $D$. wenningeri and $D$. magnodiscatum by the size of the ventral (38-41 vs. 40-46 in D. wenningeri [based on type specimens from the USNPC] and 18-24 in $D$. magnodiscatum [based on the original description of this species]) and dorsal anchors (30-36 vs. $37-41$ in $D$. wenningeri and 15-23 in D. magnodiscatum), by having 
an accessory piece with pyriform tip possessing delicate indentations on margins ("slightly enlarged tip" in the original description of $D$. wenningeri and type specimens of this species from the USNPC [see Figs. 4 and 5]), by having acute distal portion of the MCO (distal portion sinuous in $D$. wenningeri [Figs. 4 and 5]) and squamodiscs with $23-24$ rows (25-30 in D. wenningeri and 20-21 in D. magnodiscatum) (see Mizelle and Blatz 1941, Fuentes-Zambrano 1997). Although the figure legend in the original description of D. magnodiscatum (fig. 1 in Fuentes-Zambrano 1997) appears to be completely reversed compared to the legend of another monogenoidean species (Rhamnocercus margaritae [Diplectanidae]) described and illustrated by this author in the same paper, drawings of the MCO (as inverted Yshaped) suggest the presence of an accessory piece. Deposition of the type specimens of $D$. magnodiscatum (under the accession number EDIMAR no. 596) at the Museo Oceanológico Hno. Benigno Román-Fundación La Salle Campus de Margarita, Estado Nueva Esparta in Venezuela was given by Fuentes-Zambrano (1997) in the original description of this monogenoidean species. However, a request for a loan of these specimens sent to the curator (Dr. J. Capelo) of that Museo in Venezuela was un-answered. In other features, $D$. gatunense differs from other species of Diplectanum by having an accessory piece (absent in $D$. copiosum, D. monticellii and $D$. squamatum), four eye-spots ( 2 in $D$. copiosum), and by having squamodiscs covering almost all portion of the haptor (haptor laterally expanded, approximately 3 times wider than long in D. copiosum, D. monticellii and $D$. squamatum from sciaenid fishes) (see Santos et al. 2002, Boeger et al. 2006). We were not successful in locating the specimens used by Aguirre-Macedo et al. (2007) to verify the morphology of $D$. wenningeri from E. plumieri from the Caribbean Sea (Chetumal Bay, Mexico).

\section{Diplectanum mexicanum sp. $\mathrm{n}$.}

Figs. 10-17

Description (based on 25 specimens). Body 480 (400-525; $\mathrm{n}=18$ ) long, broad posteriorly; 97 (77-117; $\mathrm{n}=16$ ) wide at level of germarium. Tegument scaled on all surfaces of posterior trunk peduncle; scales plate-like with round anterior margins, lightly sclerotized, directed anteriorly. Head organs organized in four groups which are associated with each cephalic lobe; cephalic glands at level of pharynx. Eyes four; members of posterior pair larger and slightly closer together than members of anterior pair; accessory granules usually absent. Pharynx subspherical, $28(26-32 ; \mathrm{n}=11)$ in diameter; oesophagus short. Peduncle broad; haptor 109 (90-125; n $=14$ ) wide. Squamodiscs subspherical, ventral and dorsal; each formed by approximately 19-20 rings of phalangiform sclerites; anterior rings concentric, progressively tending to cover all portion of haptor; squamodisc $82(80-85 ; \mathrm{n}=4)$ long, $97(86-102 ; \mathrm{n}=5)$ wide. Anchors similar; with straight deep root, perpen- dicular superficial root, straight shaft and short point; ventral anchor $31(30-33 ; n=9)$ long, base $17(16-19 ; n$ =4) wide; dorsal anchor $31(30-34 ; \mathrm{n}=15)$ long, base 15 wide. Ventral bar $79(72-87 ; n=17)$ long, narrow, elongate, with tapered ends; paired dorsal bars 40 (39$40 ; n=4)$ long, medially expanded. Hooks similar, with elongate slightly depressed thumb, straight shaft, short point, uniform shank; filamentous hooklet (FH) loop nearly shank length; each $11(10-11 ; n=11)$ long. MCO $46(36-50 ; n=11)$ long, straight tube, elongate, with basal opening directed anteriorly. Accessory piece elongate with bifurcate tip, distally hook-shaped. Testis 25-27 wide, subspherical; course of vas deferens in relation to gut not observed; seminal vesicle a simple dilation of vas deferens, lying along body midline; prostatic reservoir pyriform, lying ventral to seminal vesicle; prostatic cells (glands) surrounding terminal portion of MCO. Germarium $51(40-57 ; \mathrm{n}=4)$ long, 47-50 wide, looping right intestinal caecum; oviduct and ootype not observed; vaginal tube sclerotized, slender and slightly undulate, distally twisted, funnel aperture, opening into small seminal receptacle lying on body midline; vitellaria dense throughout trunk, except in region of reproductive organs.

T y p e h o s t: Caitipa mojarra Diapterus rhombeus (Cuvier) (Perciformes: Gerreidae).

Site of infection: Gills.

Type locality and collection date: The coast of Campeche State, Mexico $\left(18^{\circ} 48^{\prime} 45^{\prime \prime} \mathrm{N}\right.$; $\left.92^{\circ} 03^{\prime} 45^{\prime \prime} \mathrm{W}\right)$ in the Gulf of Mexico, July 2005.

S p e c i m en s d e p o s it e d: Holotype, CNHE (6034); 10 paratypes, CNHE (6035), 7 paratypes, IPCAS (M-467) and 7 paratypes, USNPC (100848).

Prevalence and intensity of infection : Twelve fish (mean total length $10 \mathrm{~cm}$; range 9-12) infected of 12 examined (100\%); intensity 3-15 worms, mean 9 worms.

E t y m o lo g y: This species name is derived from the country from which this parasite was collected.

\section{Remarks}

Diplectanum mexicanum resembles $D$. gatunense in having an undulate vaginal tube (distally twisted) opening sinistrally, acute distal portion of the $\mathrm{MCO}$, and four eyespots. It differs from this species by having squamodiscs with 19-20 concentric rows (23-24 in D. gatunense), a shorter ventral bar (72-87 vs. 114-136 in D. gatunense), a shorter MCO (36-50 vs. 64-78 in $D$. gatunense), and by having an accessory piece which is distally bifurcate and hook-shaped (pyriform tip in $D$. gatunense).

\section{Octouncuhaptor gen. n.}

Diagnosis. Body divided into cephalic region, trunk peduncle and haptor. Tegument lacking scales or spines. Eyes present. Pharynx muscular, glandular; intestinal caeca 2, confluent in posterior trunk, lacking diverticula. Gonads slightly overlapping, testis dorsal to germarium. 

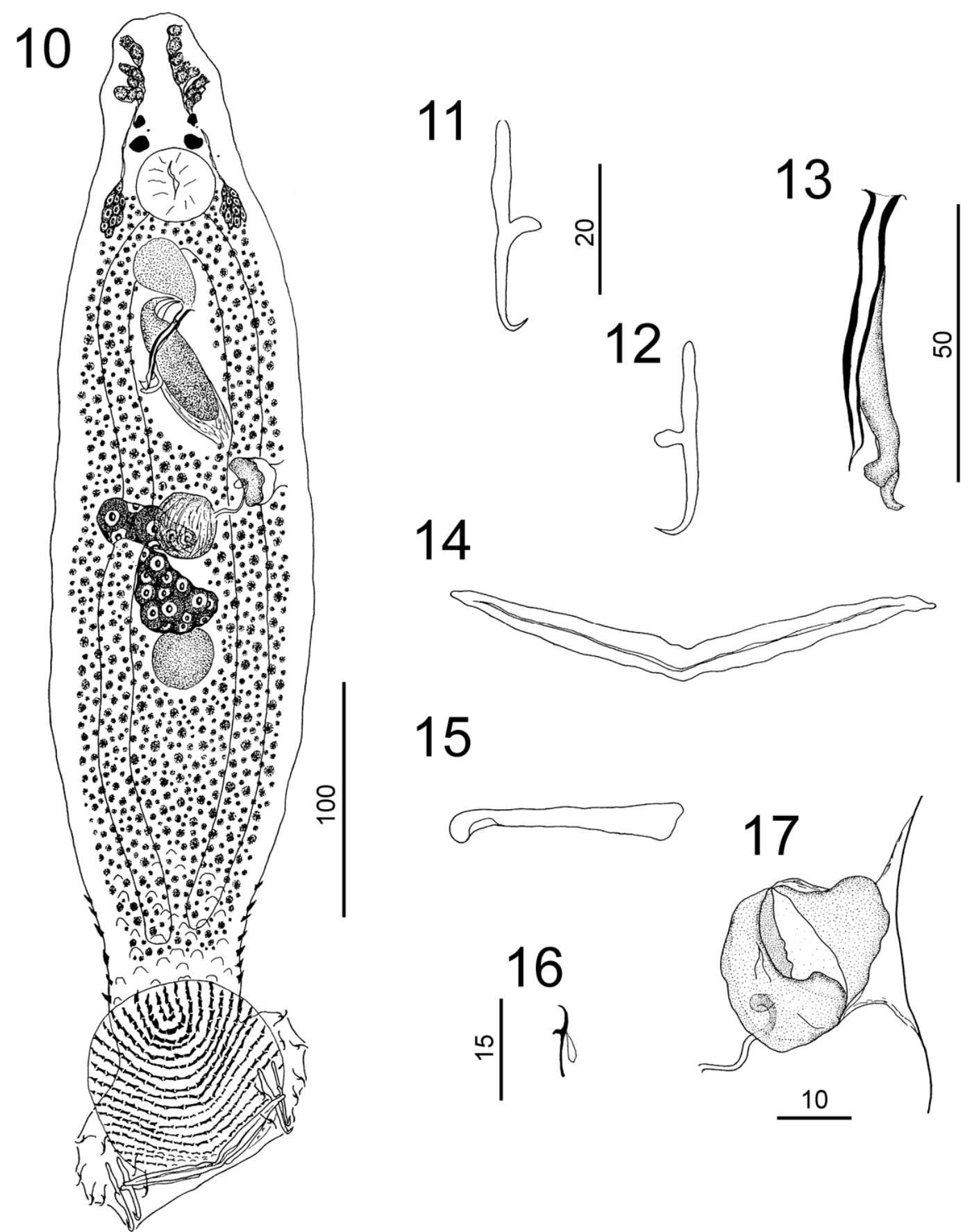

15

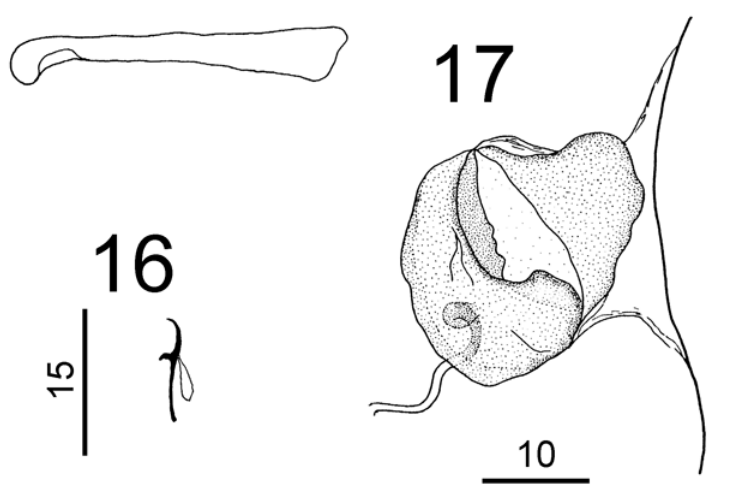

Figs. 10-17. Diplectanum mexicanum sp. n. Fig. 10. Whole mount (ventral, composite). Fig. 11. Ventral anchor. Fig. 12. Dorsal anchor. Fig. 13. Copulatory complex (ventral). Fig. 14. Ventral bar. Fig. 15. Dorsal bar. Fig. 16. Hook. Fig. 17. Vagina. Scale bars: Figs. $1-9,11,12,14,15=20 \mu \mathrm{m}$; Fig. $10=100 \mu \mathrm{m}$; Fig. $13=50 \mu \mathrm{m}$; Fig. $16=15 \mu \mathrm{m}$; Fig. $17=10 \mu \mathrm{m}$.

Common genital pore near bifurcation of caeca. Vas deferens looping left of caecum; seminal vesicle a simple dilation of vas deferens. Copulatory complex comprising sclerotized MCO and accessory piece; $\mathrm{MCO}$ a coiled tube with counterclockwise rings, base with two distal flaps; accessory piece articulated to base of MCO. Seminal receptacle anterior to germarium. Vagina sclerotized, dextrolateral, submarginal. Vitellaria follicular.
Haptor cup-shaped, armed with sixteen hooks; anchors and bars absent. Parasites of gills of Neotropical gerreid fishes. Type and only species: Octouncuhaptor eugerrei sp. n.

E t y m o 1 o g y: The generic name from Latin reflects the eight pairs of hooks on the haptor of this species (octo $=$ eight + uncu $=$ hook). 


\section{Octouncuhaptor eugerrei sp. n.}

Figs. 18-25

Description (based on 10 specimens). Body robust, fusiform $756(667-925 ; n=4)$ long, with parallel lateral margins; greatest width $175(125-270 ; n=9)$ usually at level of testis. Cephalic region with two broad lobes; each lobe with elongate zone of cephalic glands (Fig. 19). Eyes four; subequal, posterior pair longer than anterior pair; eye granules small, subovate. Pharynx spherical $83(70-95 ; \mathrm{n}=8)$ in diameter; oesophagus moderately short. Peduncle moderately broad; haptor concave, $189(148-235 ; \mathrm{n}=10)$. Hooks similar, each with protruding thumb, delicate shaft and point, dilated shank; filamentous hooklet $(\mathrm{FH})$ loop of hook extending to $50 \%$ of shank length; hook pairs $1,2,3,4,6,7$ and 8-13 $(\mathrm{n}=7)$ long; hook pair 5-17 $(\mathrm{n}=4)$ long. MCO $108(95-140 ; \mathrm{n}=5)$ long, a sclerotized tube forming one counterclockwise ring, base with two subrectangular flange. Accessory piece 55-60 long, slightly arched, articulated with base of MCO by copulatory ligament (see $\mathrm{CF}$ in Fig. 22). Vagina dextral, submarginal, an undulate and sclerotized tube, highly compressed distally, leading to medial seminal receptacle anterior to germarium. Gonads slightly overlapping, germarium 62 (46-74; $\mathrm{n}=3$ ) long, 65-68 wide; testis dorsal, 65-98 long, 80-105 wide; seminal vesicle a distal enlargement (expansion) of vas deferens; one prostatic reservoir, elongate fusiform with thick wall, anteriorly folded; oviduct, ootype, uterus not observed. Vitellaria scattered throughout trunk, but absent in region of reproductive organs. Egg $63(54-75 ; \mathrm{n}=8)$ long, $34(31-53 ; \mathrm{n}=8)$ wide, polar filament not observed. One egg observed in each one of five specimens and three eggs observed in a single specimen.

T y p e h o st: Brazilian mojarra, Eugerres brasilianus ( $\mathrm{Cu}-$ vier) (Perciformes: Gerreidae)

Site of infection: Gills.

Type locality and collection date: Gatun Lake, Panama Canal Watershed $\left(9^{\circ} 10^{\prime} 2.68^{\prime \prime} \mathrm{N}\right.$; 7950'13.90' $\left.\mathrm{W}\right)$, June 2007.

S pe ci mens deposited: Holotype, CNHE (6272); 3 paratypes, CNHE (6273), 3 paratypes, IPCAS (M-468) and 3 paratypes, USNPC (100849).

Prevalence and intensity of infection: Seven fish (mean total length $20 \mathrm{~cm}$; range 18-21) infected of $10 \mathrm{ex}-$ amined (70\%); intensity $1-3$ worms, mean 1 worm.

E t y molog y: The specific name of this species is derived from the generic name of its host, Eugerres brasilianus.

\section{Remarks}

Octouncuhaptor gen. n. is monotypic. The general morphology of the internal organ systems (intestinal caeca confluent in posterior trunk, vas deferens looping left intestinal caeca, copulatory complex comprising $\mathrm{MCO}$, accessory piece) of its type, $O$. eugerrei, justifies its placement in Dactylogyridae. It is primarily characterized by having 1) slightly overlapping gonads, 2) a basally articulated MCO and accessory piece, 3) a coiled MCO with counterclockwise rings, 4) the ab- sence of anchors and bars, 5) 8 pairs of hooks, 6) a seminal vesicle formed by a dilation of the vas deferens, 7) a dextral submarginal vaginal aperture, and 8) the presence of four eyes. Octouncuhaptor eugerrei exhibits some similarity with Aplodiscus nasalis Rogers, 1967 from the nasal cavity of Hypentelium etowanum Jordan (Catostomidae) in North America (Alabama), Anonchohaptor muelleri Kritsky, Leiby et Shelton, 1972, from the gills of Carpiodes carpio Rafinesque (Catostomidae) in North Dakota, USA, and Acolpenteron catostomi Fischthal et Allison, 1942 from the ureters of Catostomus commersonni Lacépède in Michigan, USA. These similarities are: 8 pairs of hooks (present in A. nasalis), a cephalic region laterally expanded (present in A. muelleri), and the lack of anchors and bars as in $A$. catostomi and A. muelleri (see Fischthal and Allison 1942, Rogers 1967, Kritsky et al. 1972). It differs from all these species by having intestinal caeca confluent posteriorly (not confluent in A. muelleri), by lacking anchors (one pair in A. nasalis), and by the site of infection (gills vs. nose in A. nasalis and ureters in $\mathrm{A}$. $\mathrm{ca}-$ tostomi). The characteristic absence of anchors also occurs in some freshwater species of other dactylogyrid genera, such as Anacanthorus Mizelle et Price, 1965, Anacanthoroides Kritsky et Thatcher, 1976, Kritskya Kohn, 1990 and Pavaneniella Kritsky et Boeger, 1998, among others. While phylogenetic relationships are generally unknown within the Dactylogyridae, the absence of anchors in Octouncuhaptor likely represents an example of convergent evolution rather than a phylogenetic relationship with species of the latter genera.

\section{DISCUSSION}

Diplectanum gatunense from Panama and D. mexicanum from Mexico are added to the two previously described species of Diplectanum (D. magnodiscatum and $D$. wenningeri) from gerreid fishes (Mizelle and Blatz 1941, Fuentes-Zambrano 1997). As previously suggested by Kritsky et al. (2000) and Domingues (2004), the morphological boundaries within Diplectanum are not well established and species within this genus exhibit a high degree of variability (i.e. presence/absence of an accessory piece, position of the vaginal aperture and morphology of the copulatory complex, among others). Additionally, other species of Diplectanum are found on a wide range of other host families including Sillaginidae (Indo-west Pacific), Toxotiidae (from India to the Philippines, Australia and Polynesia), Moronidae (Eastern North America and Europe), Polynemidae (Indo-Pacific, East Africa to French Polynesia), Latidae (Indo-Pacific, Africa), and Sphyraenidae (Caribbean and Occidental Atlantic) (Kritsky et al. 2000, Kohn et al. 2006). These may represent polyphyletic taxa (see Domingues 2004). Thus, differences in morphological characters could aid in determining monophyletic groupings within Diplectanum. 


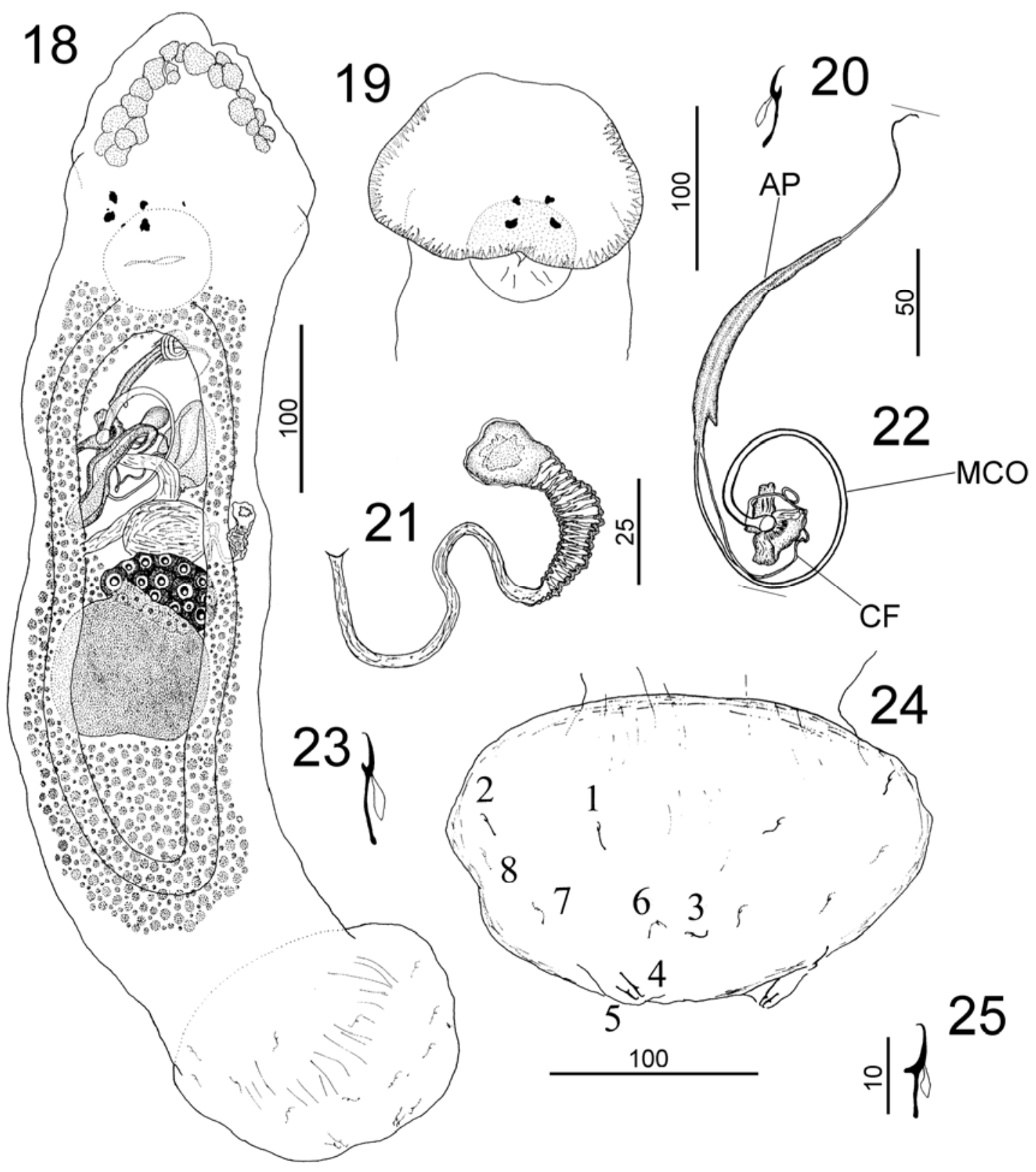

Figs. 18-25. Octouncuhaptor eugerrei sp. n. Fig. 18. Whole mount (composite, dorsal view). Fig. 19. Cephalic region (bent dorsoventrally). Fig. 20. Hook (pair 3). Fig. 21. Vagina. Fig. 22. Copulatory complex (dorsal view) (two parallel lines indicate dimension measured). Fig. 23. Hook (pair 4). Fig. 24. Ventral view of haptor showing positions of hook pairs. Fig. 25. Hook (pair 5). Abbreviations: AP - accessory piece; CF - copulatory filament; MCO - male copulatory organ. Scale bars: Figs. 18, 19 $=100 \mu \mathrm{m}$; Figs. $20,23,25=10 \mu \mathrm{m}$; Fig. $21=25 \mu \mathrm{m}$; Fig. $22=50 \mu \mathrm{m}$; Fig. $24=100 \mu \mathrm{m}$.

For example, D. gatunense, D. magnodiscatum, D. mexicanum and $D$. wenningeri more closely resemble each other compared to species parasitizing marine and freshwater sciaenids from South America. Consistent with this, both the Atlantic Gerreidae and Sciaenidae appear to be well separated on the basis of morphological and molecular analyses, but co-occurring in the same geographical area, i.e. Western Atlantic (Deckert and Greenfield 1987, Vinson et al. 2004, Chen et al.
2007). This separation into the phylogenetic context could have resulted in parasite speciation for each host family. Our examination of $D$. wenningeri, the original description of $D$. magnodiscatum, and the current description of $D$. gatunense and $D$. mexicanum, provide evidence that they share the following synapomorphies: a tubular MCO with an accessory piece, squamodiscs almost entirely covering the haptor and a distally twisted vaginal tube (present in D. gatunense and $D$. 
mexicanum) (Figs. 9 and 17). Host switching within Gerreidae may have resulted in speciation of this parasite clade. For example, D. wenningeri has been reported from Eugerres plumieri, a host species which is genetically related to Diapterus auratus (Gerreidae) in the Atlantic (see Ruiz-Carus and Uribe-Alcocer 2003) along the Caribbean coast of southern Mexico (AguirreMacedo et al. 2007). Although D. auratus has not been reported as a host of any Diplectanum species, further sampling could demonstrate the close resemblance expected among species of Diplectanum on these gerreid fishes. Furthermore, parasitological examination of other closely related host species within the genus Eugerres may elucidate the phylogenetic relationship of Diplectanum within respective hosts.

In contrast, Octouncuhaptor eugerrei found on $\mathrm{Eu}$ gerres brasilianus in Panama does not appear to be closely related to any known dactylogyrid species. Other monogenoidean species within the genera Encotyllabe Diesing, 1850 (Capsalidae), Microcotyle van Beneden et Hesse, 1863, Polylabris Euzet et Annie, 1967 (Microcotylidae) and Pseudohaliotrematoides Ya- maguti, 1953 (Dactylogyridae) have been reported from the gills of gerreid fishes (see Hayward 1996, Kohn et al. 2006, Kritsky and Galli 2007) and they do not show any morphological similarity with $O$. eugerrei. Thus far, Octouncuhaptor is composed of a single member with a highly unusual characteristic: distribution of eight pair of hooks in the haptor. Unlike the typical arrangement of seven pairs of hooks present in most Dactylogyridae (see Mizelle 1936), eight pairs are only present in a few dactylogyrid species (e.g. species of Anacanthorus Mizelle et Price, 1965 and Anacanthoroides Kritsky et Thatcher, 1976 parasitizing piranhas in Brazil).

Acknowledgements. We thank M. Hernandez-Santillana and D. Arceo (CINVESTAV-Merida, Mexico) for collecting $D$. rhombeus from the Gulf of Mexico. D.R. Robertson (Smithsonian Tropical Research Institution - STRI) identified the specimens of E. brasilianus and P. Pilitt from the U.S. National Parasite Collection provided cotype and voucher specimens of $D$. wenningeri for study. Financial support was provided by the STRI through a postdoctoral fellowship to EFMF. DGR acknowledges grants from NSERC and OQAJ for supporting the field work of this study.

\section{REFERENCES}

AgUiRRE-MACEDO M.L., VIDAL-MARTÍNEZ V., GONZÁLEZSOLÍs D., CABALlERO P.I. 2007: Helminth communities of four commercially important fish species from Chetumal Bay, Mexico. J. Helminthol. 81: 19-31.

Boeger W.A., FeHLAuER K.H., MARQues E.E. 2006: Neotropical Monogenoidea. 49. Four new species of the Diplectanidae (Dactylogyrinea) from the gills of some pachyurines (Teleostei: Sciaenidae) from the Rio Tocantins and Rio Doce Basins, with the proposal of Anoplectanum n. g. and Spinomatrix n. g. Syst. Parasitol. 64: 57-68.

CHEN W.J., RuIZ-CARUS R., ORTI G. 2007: Relationships among four genera of mojarras (Teleostei: Perciformes: Gerreidae) from the western Atlantic and their tentative placement among percomorph fishes. J. Fish Biol. 70 (Suppl. B): 202 218.

DECKERT G.D., GREENFIELD D.W. 1987: A review of the Western Atlantic species of the genera Diapterus and Eugerres (Pisces: Gerreidae). Copeia 1: 182-194.

DOMINGUES M.V. 2004: Filogenia e taxonomia de Diplectanidae Monticelli, 1903 (Platyhelminthes; Monogenoidea). Ph.D. Thesis, Universidade Federal do Paraná, Brazil, 217 pp.

DOMINGUES M.V., BOEGER W.A. 2003: Neotropical Monogenoidea. 43. Diplectanum monticellii n. sp. (Diplectanidae) from the gills of Cynoscion leiarchus (Perciformes: Sciaenidae) in Brazil. J. Parasitol. 89: 698-700.

Fischthal J.H., Allison L.N. 1942: Acolpenteron catostomi n. sp. (Gyrodactyloidea: Calceostomatidae), a monogenetic trematode from the ureters of suckers, with observations on its life history and that of $A$. ureteroecetes. Trans. Am. Microsc. Soc. 61: 53-56.

Froese R., PAUly D. (Eds.) 2008: FishBase. World Wide Web electronic publication. www.fishbase.org, version (03/2008).

FUENTES-ZAMBRANO J.L. 1997: Dos especies nuevas de monogeneos (Diplectanidae) parásitos de peces marinos de la Laguna de la Restinga. An. Inst. Biol., UNAM, Ser. Zool. 68: 225-236.

HAYWARD C.J. 1996: Revision of the monogenean genus Polylabris (Microcotylidae). Invertebr. Taxon. 10: 995-1039.
KoHN A., COHEN S.C. 1998: South American Monogenea. List of species, hosts and geographical distribution. Int. J. Parasitol. 28: 1517-1554.

Kohn A., Cohen S.C., Salgado-Maldonado G. 2006: Checklist of Monogenea parasites of freshwater and marine fishes, amphibians and reptiles from Mexico, Central America and Caribbean. Zootaxa 1289: 3-114.

KRITSKY D.C., GALli P. 2007: Dactylogyrids (Monogenoidea) parasitizing the gills of spinefoots (Teleostei: Siganidae): revision of Pseudohaliotrema, with redescriptions of $P$. sphincteroporus and $P$. molnari from the great barrier reef Australia. Comp. Parasitol. 74: 9-22.

KRITSKY D.C., THATCHER V.E. 1984: Neotropical Monogenea. 6. Five new species of Diplectanum (Diplectanidae) from freshwater teleosts, Plagioscion spp. (Sciaenidae), in Brazil. Proc. Biol. Soc. Wash. 97: 432-441.

KRITSKY D.C., BOEGER W.A., THATCHER V.E. 1985: Neotropical Monogenea. 7. Parasites of the pirarucu Arapaima gigas $(\mathrm{Cu}-$ vier), with descriptions of two new species and redescription of Dawestrema cycloancistrium Price and Nowlin, 1967 (Dactylogyridae: Ancyrocephalinae). Proc. Biol. Soc. Wash. 98: 321-331.

KRITSKY D.C., JimÉnEZ-RUIZ F.A., SEY O. 2000: Diplectanids (Monogenoidea: Dactylogyridea) from the gills of marine fishes of the Persian Gulf off Kuwait. Comp. Parasitol. 67: 145-164.

KRITSKY D.C., LeIBY P.D., Shelton M.E. 1972: Studies on helminths of North Dakota. IV. Parasites of the river carpsucker, Carpiodes carpio, with descriptions of three new species (Monogenea). J. Parasitol. 58: 723-731.

MizELLE J.D. 1936: New species of trematodes from the gills of Illinois fishes. Am. Midl. Nat. 17: 785-806.

Mizelle J.D., BLATZ V. 1941: Studies on monogenetic trematodes. VI. Two new dactylogyrid genera from Florida fishes. Am. Midl. Nat. 26: 105-109.

OLIVER G. 1987: Les Diplectanidae Bychowsky, 1957 (Monogenea, Monopisthocotylea, Dactylogyridea). Systématique. Biologie. Ontogénie. Ecologie. Essai de phylogenèse. DSc 
Mendoza-Franco et al.: New Monogenoidea from gerreid fishes

Thesis, Université des Sciences et Techniques du Languedoc, Montpellier, $433 \mathrm{pp}$.

Oliver G. 1993: Les Diplectanidae Bychowsky, 1957 (Monogenea, Monopisthocotylea, Dactylogyridea) marqueurs biologiques, temoins de la biogéographie et de l'évolution de leurs hôtes. Bull. Soc. Zool. Fr. 118: 25-36.

Rogers W.A. 1967: Studies on Dactylogyrinae (Monogenea) with descriptions of 24 new species of Dactylogyrus, 5 new species of Pellucidhaptor, and the proposal of Aplodiscus gen. n. J. Parasitol. 53: 501-524.

RUIZ-CARUS R., URIBE-AlCOCER M. 2003: Phylogenetic assessment of Eucinostomus gula, Eugerres plumieri, and Diapterus

Received 4 March 2008 auratus (Pisces: Gerreidae) based on allozyme and mtDNA analyses. Caribb. J. Sci. 39: 109-115.

SANTOS C.P., TIMI J.T., GiBSON D.I. 2002: Diplectanum squamatum n. sp. (Monogenea: Diplectanidae) from the gills of $\mathrm{Cy}$ noscion guatucupa (Sciaenidae) in Southwest Atlantic waters. Syst. Parasitol. 52: 199-204.

VinSON C., GOMES G., SCHNEIDER H., SAMPAIO I. 2004: Sciaenidae fish of the Caeté River estuary, Northern Brazil: mitochondrial DNA suggests explosive radiation for the Western Atlantic assemblage. Gen. Mol. Biol. 27: 174-180.

Accepted 28 April 2008 